\title{
Frotectionism: Old Wine in New Bottles
}

Jagdish N. Bhagwati, Columbia University

This paper addresses some rew types of arguments that have recently arisen in defense of protectionism in developing and developing countries. The new sources of protectionism in developing countries discussed are: (1) recession-debt-crisis costs; (2) protection in the world economy; (3) wages a rid labor markets; (4) political requirements. The new arguments for protectionism in developed countries discussed are: (1) shift to the service economy; (2) defense; (3) thren t of protection to induce foreign investment.

Protectionism has always reared its familiar head when unemployment has risen and competition has gotten tough. Both these reasons have certainly contributed to the recent resurgence of the threat to the postwar environment of freer trade that generated rapid growth in both trade and incomes for nearly three decaies. The major recession in the first Reagan term and the continuing high levels of unemployment in European countries despite the revival of the United States economy are the source of the macroeconomic threat. Morenver, the vast debt carried by Latin America fuels their need for more exports and adds to the difficulties of specific industries in the mature economies that must adjust to the relatively more rapid growth of outward-oriented economies of the Far East. Indeed, the growth of Japan "squeezes" the industries at the upper end of the technological spectrum whereas the growth of the Gang of Four (Taiwan, South Korea, Klong Kong, and Singapore) has been pressuring the indistries at the lower end of that scale, resulting in " "pincer movement" that has fed the demands for protection from these industries.

This paper, however, does not address the specifics of the current protectionist situation as they reflect these economic phenomena. Instead, I choose to discl $s$, here certain new types of arguments in defense of protection that lave recently arisen. I divide these arguments into two classes: the on $s$ that have arisen in the developing countries

Address correspondence to Jugdish N. Bhagwcti, Arihur Lchman Professor of Economics and Director, International Economics Reiearch Center, Columbia University, New York, :VY 10027.

Received Vovember 1984. accepted December 1984.

'ournal of P'olicy Modeling 7(1):23-33 (1985)

( Society for Policy Modeling, 1985

$0161-8938 / 85 / \$ 3.30$ 
(Section 1); and those that have surfaced in the developed countries (Suction 2). ${ }^{1}$

\section{ARGUMEN IN THE DEVELOPNG COUNTRIES?}

The arguments in favour of protection in the developing countries arise essentially in the form of a resurrection of the assertion that the import-substituting (IS) strategy is preferable to the export-promoting (EP) strategy. Raised at the outset of the postwar perod, and indeed forming the basic core of the dobate over the ideal developmental strategy for the developing countries, this issue was settled in favor of the EP strategy by the remarkable success of the countries (in the Far East) that followed it: precepts. Numerous studies, organized by several distinguished economists, led thereiore to the demise of the notion that the IS strategy was the appropriate one, among the principal such studies being that done at the World Bank by Bela Balassa (1982), that done at the OECD by lan Little, Tibor Scitovsky, and Maurice Scott (1970), and those done at the NBER by Bhagwati (1978) and Krueger (1978).

Recently, however, questions have been raised, with influential impact in some developing countries, concerning the advisability of the EP strategy, thus implying the desirability of an inward-looking, protectionist policy stance by the developing countries. As argued below, these are legitimate, though somewhat misplaced, doubts in my view. Their currency, however, is partly due to the "nationalistio" reaction that intellectuals in some of these countries have to the fact that the EP strategy has been turned into an important component of conditionality at the World Bank at a time when many countries are seekirig help from. the international institutions.

The new sources of protectionist sentiments are basically fourfold.

\section{A. Recession-cum-Deb1-Cricis Costs}

During the postrecession years of the late 1970s a -1 early 1980 s, it is asserted that the EP countries must have sufferen a greater adverse

\footnotetext{
${ }^{1}$ There are also a few theoretical arguments that have veen advanced in the literature, based essentially on the introduction of market structures such as oligopoly and imperfect competition. In my judgnent, their empirical relevance is not great, and several key results supportive of protection are critically dependent on absence of free entry into the market studied. A proper examination of these arguments, however, would take ne far bcyond the scope thai I have defined for the present raper.

2The structure of the argument advanced in this section closely follows a recent discussion of the suiject in my contribution to the Festschrift for Saburo Okita: see Bhagwati (1985).
} 
impact than the IS countries in view of their exposure to the external environment. Insofar as the EP countries were also on a debt-led growth path, the debt crisis and the adjustments imposed by the collapse of the world credit markets would have forced yet greater costs on these countries. Is proponer ts would therefore feel vindicated.

However, vix fact rrmains that the Far Eastern economies that were into EP stracegy in tile most pronounced fashion remained the best growth performers even as they slowed down with the rest of the world. In fact, Bela Balassa's (1982) cross-sectionil analysis of comparative performance of the EP and IS countries during this lean period suggests little to confirm the sLggestion that outward orientation has made countries fare worse. Moreover, the EP countries grew so much better during the many years preceding this lean period that any proper costbenefit calculus would have to take into account earlier successes and set them off against the later losses (if there were any).

\section{B. Protection in the World Economy}

If the world-trade environment is being overwhelmed by protection, would that not be a ground for retreating into the IS strategy? Tnere are really several levels at which this agument can be addressed. First, adjusting for the income effects of the lasie recession, it is not clear that the actual protectionist effect on trade has been sufficiently severe to make us fear that the world trade order has begun to collapse. There are good reasons to infer rather that world $t$ ade has shown remarkable resilience in the face of these fears and threats, that the bark has been more evident than the bite, and that the revival of export pessimism may be premature. ${ }^{3}$ Second, even if the world markets do not expand rapidly, this does not mean that developing countries will necessarily face, for individual decision malking, a less than perfectly elastic offer curve: the offer curve may be fully elastic at any point of time while shifting steadily over time toward the developing country's offer curve. In that event, the case for an IS strategy does not legitimately derive from the traditional optimal-tariff-for-a-large-country argument. Third, I should like to amphasize that I do not find persuasive the frequent contention that the Far Eastern economies' EP model cannot be exported because if eiery developing country exports like them, the world cannot possibly aiosorb the resulting exports. This argument is often buttressed by raising all

\footnotetext{
${ }^{3}$ On this point, see the interesting paper of Bela and Caro Balassa (1984) in The World Economy which takes, consistently also with work by Anne Krueger and Helen Hughes at the World Bank, an optimistic view of world trade trends in the teeth of protectionist voices and actions.
} 
developing countries' expcrts to the same share of GNP as in the Far Eastern economies. But the EP strategy simply implies eliminating the bias against ex ports. There is no reason to conclude that this would yield, for every country, the same share of trade to GNP as for the small group of current EP countries. Moreover, such extrapolations ignore the fact that trade can occur in all kinds of differentiated products and in unpredictable ways. Export pessimism in the 1950 was in no small part a result of the inability of planners in developing countries to think up, in their armchairs, the possible sources and composition of trade expansion. For example, before the trade in similar products seized our empirical and theoretical attention, who could have not thought that "similar economies" would have less, rather than more, trade with one another? Again, devaluations are ofter successful in promoting exports of "miscellaneous" items that no bureaucrat or economist can predict but which the opportunity for gainful trade seems often to yalvanize. Finally, the fact that rapid trade expansion, if many more countries chose the EP strategy. could put pressure on specific sectors in specific countries cannot be denied. But interestingly, the reaction need not be simply protectionist but may also be to pressure one's rivals into freer triade as, in fact, is happening in the case of Japan at the insistence of Europe and the United States. Expanding trade needs may therefore snsure that the Western leadership may redouble its efforts to keep doors open and to open other people's doors.

\section{Wages and Labor Markets}

A recent argument against the adoption of the EF strategy has been advanced by Gary Fields (1984). Contrasting the Far Eastern economies principally with the countries of the Caribbean, Jamaica included, he has argued in effect that these countries have suffered from excessively high wages that make protection desirable, and that their reliance on the EP strategy has therefore been harmful rather than neipful.

However, Fields does not establish; I am afraid, the basic contention that these countries have an EP strategy in the first place. As has been explained systematically in the Bhagwati (1978) and Krueger (1978) synthesis volumes from the NBER project, the EP strategy simply consists in eliminating the bias against exports implied by the (overvaiued exchange rates, protection, etc. resulting in the) IS strategy. As far as one can tell, Fields has not produced the evidence on the relative eff sctive exchange rates on exports $\left(E_{E R R_{x}}\right)$ and on imports $\left(E^{2} R_{m}\right)$ that would support his contention that these are EP countries, i.e. that they 
are characterized by $\mathrm{FER}_{x} \approx \mathrm{EER}_{m}$ rather than by $\mathrm{EEl}_{m}>\mathrm{EER}_{x}$ as with the IS countries. In fact, for Jamaica at least, I am assured that my presumption that it is really a classic case of an IS strategy is corroborated by such ex idence. Fields, like many other commentators who are unfamilial with the careful analytical concepts ir the literature, seems to have confused 'he island nature and smallness (with asscciated high ratios of trade tc (GNP) ${ }^{4}$ of these countries with the altogether differert $c 0: t^{+}$of wha: is an EP strategy. ${ }^{5}$

Besides, noi. that the theoretical contention that labor market imperfections may require a departure from the EP st:ategy is well known from the work of trade theorists, including . Richard Bre:her, V.K. Ramaswarii, T.N. Srinivasan, Harry Johnson, myself, and others, during the 1960s. Their demonstration that the optimal policy intervertion in these cases is to intervene in the factor inarkets directly--see

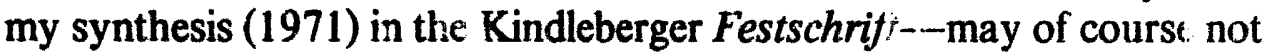
be feasible where political or institutional factors inhibit the implemeintation of such policies. If this case is persuasively established, then a protect onist departure from the EP strategy may we:l make sense. But $\mathbf{J}$ see no such case plausibly established for Fields' Caribbean countries either.

Fields' reliance rather on the argument that wages are kept uncer control in the Gang of Four countries seems to me to point to a very different general-equilibrium theoretic $\mathrm{ar}_{6}$ ument of microeconomics. The Jang of Four countries : ppear to have used authoritarian metho is to $k$ sep trade unions under :ontrol and to build or: this a successful $\because$. ro policy of low inflation. The good microeconon ics of EP strates y has then been built on the nesessary macro foundations without which one would likely lapse into repeated overvaluations, occasional exchinge controls, and the attendant inefficiencies of implied import substitution, I have already hinted at this explanation in iny NBER syn'hesis volun:e (1978), but it is a thesis that requires intensive empirical analysis fic $r$ validation.

\section{Political Requirements?}

Many critics of EP strategy have been worrisd about th e associition of this strategy with the authoritarian regimes of the Far Easter.

\footnotetext{
${ }^{4}$ On four alternative ways of difining these ratios, anıl their conce;tual underpin rings sic the important recent paper by Padra Desai (1984).

5hus, an EP strategy is wholly consistent with a "low" ratio of trade tc GNP, howevet defincd.
} 
countries. Does this not imply that the iron fist is essential for the adoption and successful implementation of this strategy?

Of course, since many developing countries are unfortunately authoriterian, this would not constitute a barrier to the adoption of the EP strategy. Less cynically, however, the argument simply ignores the fact that many totalitarian countries (e.g. the USSR) have been on the IS strategy, whereas within the Far Eastern economies, the degree of authoritarianism varies, and not necessarily monotonically with respect to their economic performance. It is possibly safe to say that there are no necessary or sufficient conditions to be found here.

I would venture, however, to suggest the modest hypothesis that it has been hard for democratic countries such as India to transit from their early IS strategy, and easy for the less democratic and more authoritarian countries of the Far East to embrace the EP strategy after a brief IS phase, simply because pluralistic democracies may find it much harder to dismantle the controls, protection, etc. that inevita:ly accompany the IS strategy-because, in turn, these policy instruments carry patronage and confer on the politicians the power to collect funds fior their reelection, so that the economic regime unuter the IS strategy sends to become a critical source of politicel power. By contrast, in authoritarian regimes, the political power is seized directly, freeing the rulers to shift to the EP strategy with its dirninished patronage potential. ${ }^{6}$

A "satisficing" political theory has recently been advanced by John Ruggie (1983) and his associates, all distinguished political scientists, suggesting that the advantages of an EP strategy cannot be exploited by political regimes that cannot successfully address the disuributional conflicts and tencions that would follow frora this strategy. Fundamentally, this appears to me to be a persuasive argument as far as the acceptance or political feasibility of any developmental strategy is Oucerned. Where I part company from Ruggie and his associates is in the implied contention that the EP strategy leads to mc.e such demands on the political system. An IS strategy, while relatively insulating the system from external disturbances, may create yet more tensions if the $i$ csulting luss of income expansior, accentuates the zerc -sum nature of the cther policy options in the system. Therefore, I would rather convert the Ruggie thesis from its current version into ihe necessary and valid caveat that, in pursuing any developmental strategy, one must consider its compatibility with the political structure and resilience of the country.

\footnotetext{
${ }^{6}$ I have advc nced this hypothesis in Bhagwati (1978), drawing on elements of the argument in Bhagwati and Krueger (1973).
} 
And this particular cavea: is, I would stress, not one that I would address only to EP-strategy proponents.

The caveat does imply, in my view, that those who seik to include the EP strategy as a necessary ingredient of conditionality imposed by the World Bank or the IMF, as is, for exzmple, the cuse with many Structural Adjustment Loans from the Bank, should t e urged to exercise some caution lest their prescriptions be counterprorluc,ive because of ignored political prerequisites. The unduly harsh wit icis'n aimed at the distinguished Nicholas Kaldor, that political upl eavils follow his advisory missions, is an excellent corrective to thos: who fail to place their economic prescriptions in their political contex:

\section{ARGUMENTS IN THE DEVELOPED COUN'RIIIS}

Let us turn now to the arguments for protection the.t ha ve arisen in the developed countries.

\section{A. Shift to the Service Economy}

Interestingly, the rise of modern service industries, reflecting the rapid growth of the information technologies, has led tc two pro:ectionist arguments, each in fact diametrically opposed to the other in its intellectual foundations.

On the one hand, we have the demand, especially: from Nicholas Kaldor and his associates in Cambridge, for "reinddustrialization", a sentiment supported in the United States by the sowiologis: Amitai Etzioni. The main contention of Kaldor seems to bs that there are externalities associated with industrialization that would be lost otherwise. In particular, Kaldo:'s $\left(1966,197^{\circ}\right)$ views seem to rest on the socalled Verdoorn (1949) finding that gro'wth of productivity is nigher in : the manufacturing sector, a finding that also led him to recomr irend the Selective Employment Tax to Chancellor of the Excheq/er Mr. Callahan ? to shift employment into manufactures. I am afraid, how ever. that this argument erroneously identifies low productivity with s:rvices as against manufactures, reflecting the identification by Britis sconomists $o$ servicas witn ineftıcient retailing and other traditionally low-productivit: sectors in their economy. The argumen $i$ is totally aisleading when $i$ comes to modern, highly rogressive service sectors.

${ }^{7}$ I have discussed this issuc, anc the possible reasons underling he prevalence of the views in Britain, in an article in '" he World Economy (Bhagwati 384 ). 1 might varn t/" reader that there is also a nacro theoretic rationale advanced in (fmbridge, England. fo protection; but that has been co the ed at length alscwhere in $1 /$ Symposium. 
Or the other hi.nd, m.any intellectuals and policymakers in the developed countries have begun identifying high-tech and information industries-cum-services as the cutting edge of the modern age, and this has led to the dernand that, no matter what the market dictates, governments should assure that their nations get these activities established domestically through implicit or explicit protection. This is reminiscent of the demand for protection of manufactures in the developing countries in the postwar years: few developing countries would have been willing to let the market, i.e. comparative advantag assign them to a paiely primary-product specialization! For this reason, I find this to be a potentially difficult area for GATT to monitor effectively. Politicians will simply be obdurate, I am afraid, in the face of advice from economists on this question.

\section{B. Defense}

Surprisingly, the traditional argument for protection in order to promote defense industries has recently been revived by Paul Seabury (1983), a distinguished political scientist, in the context of the basic or smokestack industries and therefore in favour of "reindustrialization", for the United States. It is best to let him talk:

Indeed, in light: of the deteriorating statc of its basic industries, the United States has a clear need for a coherent industrial policy, but for reasons wholly unrelated to thos asually offered. The necessity for a U.S. industrial policy arises not from comestic economic considerations-however large these may currently loom-- but rather from strategic-military concerns. As the only genuine guarantor of security for both itself and the Free World as a whole, the United States sinply cannot afford to allow its industrial base to wither aw ay ... The American industrial base constitutes the strategic core of Free World defenses. Those who, whether in the interests of free trade or a "high tech" b :om, are content to remain untroubled by the demise of U.S. basic industry would do well to remember Solon's stern warning to Croesus: Sir, if any man hath better iron than you, he will be master of all this go'd. (1983, pp. 5-6)

This argument sounds wholly implausible to me, er 1 though Stabury examines in detail the ways in which lack of domestic capacities in the basic industries might impact on conflagrations between the sujerpowers. He reaily would have to discount the possibility of drawing on supplies from the U.S. allies during such episodes. He would also havis to ignore the possible pelicy option of storing supplies that may not be so accessible: nuts ano bolts, not just tanks and oil, are capable of biing stored. Anc if the shift to high-tech and modern services is indecd advantageous, I doubt immensely that the storage costs of "sensitive" 
basic-industry items would outweigh the costs of foregoing such a shift of specialization in response tos shifting comparative advantage. Besides, there is also the "systemic" point that the United States cannot invoke this argument for protecting its basic industries without having serious impact on the "rule of law," as embodied in GATT. Can anyone seriously believe that the other GATT members would accept sucil an argumentation by the United States without cynicism? GATT is under enough pressure as it is without the United States, a principal actor on the scene, resorting to protection on such an implausible argument. ${ }^{8}$

\section{Threat of Protection to Induce Foreign Investment}

A rather remarkable develc pment in the developed countries in recent years has been the use of the threat of protection to induce foreign competitors in specific industries to invest in one's own country. This is reminiscent of the developing countries, especially those following the IS strategy, using actual protection to induce such investment inflows into specific sectors.

This type of direct foreign investment (DFI) is evident from the GlMToyota deal in the United Stctes, apparently prompted by the threat of domestic-content protection--which was very real prior to the imposition of VERs (voluntary export restrictions) on exports of autos by Japan to the United States. The quid pro quo for Toyota in this deal, which benefits General Motors and creates jobs for the United Auto Workers (UAW) union, is evi lently the conversion of General Motors to a frce-trader stance in local 'J.S. politics: this is manifest from the fact: that GM alone amo $y$ the U. j. automakers has been arguing against the: extension of the auto VERs."

\footnotetext{
${ }^{8}$ Since Seabury does not really go into the question of alternative ways in which such protection may be provided, I should remind the reader that the theory of noneconomic objectives recommends that defense industries be protected not by tariffs hut by domestic production subsidies.

${ }^{9}$ It may be of interest to the readers to note that this kind of mutur I-gain deal, which promotes joint investments and hence is a specific DFI "type," ma: be contrasted with another DFI "type," which I developed in Bhagwati (1972) in a review of Vernon's work and which I have later elaborated in Bh igwati (1982). This type of DFI, which I christened the MPI (Mutual Penetration of Investment), involves mutual investment by GM in Toyota to produce the small cars the Japanese are better at, and by Toyota in GM to produce the larse es is the Americaus are better at, for reasons of his'orical specialization. This idea was sugge sted to me by the Dunlop-Pirelli DFI deals where each bought into the other's specializatio 1. I was conirasting the MPI medel with Vernon"s celebrated "product sycle" model and pedicting that the MPI model wuld be the wave of the future, just like trade in "similar products." For the time being, huwever, it seems to be partly displaceu
} 
This model has its attractions and, I am afraid, it will draw in more imitators, as unions try to protect their specific jobs by thr :atening protection as an induceme it to the foreign producers to manufacture here rither than there.

\section{REFERENCES}

Balassa, Bela (1982) Development Strategies in Semi-Inaiustrial Econcmies. Baltinore: Johns Jopkins University Press.

Balassa, Bela (1983) External Shocks and Adjustment Policies in 12 Less s. siuped Countries: 1974-76 and 1979-81. Paper presented to the Annual Meting of the Ani rican Economie Association, San Francisco, December.

Balassa, Bela, and Balassa, Carol (1984) Industrial Protection in the Developed Countries. The Wor'd Economy 7(2):179-196.

Bhagwai Jagdsh N (1971) The Generalized Theory of Distortions and Welfare. In Trude, Baiance of Payments and Growth: Essays in Honour of Kindieberger (J. Bhagwat ot al., eds.). Amsterdam: North Holland Co.

Bhagwati, Jagdish N. (1972) Review of Sovereignty at Bay by Raymond Vernon. Journal of International Economics $455-459$.

Bhagwati, Jagdish N. (1978) The Anatomy and Consequences of Exchange Control Regimes. Cambridge, MA: NBEF, Ballinger \& Co.

Bhagwati, Jagdish N. (1982) Shifting Comparative Advantage, Protectionist Demands, and Policy Response. In Import Competition and Response (J. Bhagwati, ed.). Chicago: NBER, C.h zago University Press.

Bhagwati, Jagdish N. (1984) Splintering and Disembodiment of Services and Developing Nations. The World Economy 7(2):133-144.

Bha!r, ati, Jagdish N. (1985) Export Pro notion as a Development Strategy. In Essays in sionor of Saburo Okita (T. Shi hido and R. Sato, eds.). MA: Auburn House Publishing Co.

Bhagwati, Jaguish N., and Krueger, Anne O. (1973) Exchange Coritrols, Liberalization and Eccnomic Development. American Economic Review 419-427 (May).

Desai, ladma (1984) Fow Should the Role of Foreign Trade in the Soviet Economy be Measured? Intentational Economics Research Center, Columbia University, Vorking Paper No. 42.

Fields, IJary (1984) Enployment, Income Distribution and Economic Growth in Seven Small Open Ecriomies. Economir Journal 994:74-83.

Kaldor, Nicholas (1966) Causes of the Slon' Economic Growth of the United' Kingdom. Cambridg. U.K.: Cambridge University Ptess.

Kaldor, Nicholas (1975) Economic Growth and the Verdoorn Law 1 Comment on Mr. T.owthorn's Article. Economic Journol \$91-896.

Krueşer Aane Osvorne (1978) Liberalization Attempts and Consequences Cambridge, A.A: NBEK, Ballinger \& Co.

\footnotetext{
from the center stage by the model-type that 1 am discussing in the text, wher : the foreigin competitor.' quid r. ro quo comes not from their investing in your specialized $k$ wowh,$w$, but

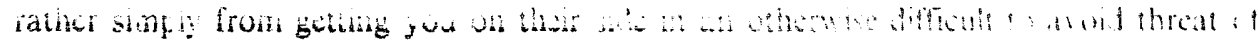
protectionist actions.
} 
Krueger, Anne Osborne (198?) Trade ant Emptoyme" in Developing Countrex Synthesis and $C$ mi husions \& cago University of (hilago Press

Litlle, lan. Schousti, ishor and cott Ma mo (1970)/ tdisiry and Trade in Somis

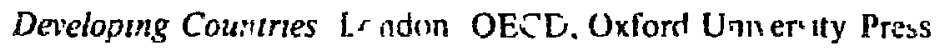

Rugghe, John Gerard, sd. (19'5) The Aninomls of interd 'perdence itatinnal W'e!fare and the Imternational Division of Labor. New York: Columbia University Press.

Seabury, Paul (1983) Industral Policy and National Defense Journal of Conternporary Studies, 5-15.

Verdoorn, PJ. (1949) Fatton che regolano lo sthupjo cella p-orittività del lavoro, L'Industrin, $1 \cdot 3-11$. 